\title{
Leaf extracts from Nitraria retusa promote cell population growth of human cancer cells by inducing apoptosis
}

\author{
Jihed Boubaker ${ }^{1,2}$, Wissem Bhouri ${ }^{1,2}$, Mohamed Ben Sghaier ${ }^{1,2}$, Ines Bouhlel ${ }^{1,2}$, Ines Skandrani ${ }^{1,2}$, Kamel Ghedira ${ }^{2}$ \\ and Leila Chekir-Ghedira ${ }^{1 *}$
}

\begin{abstract}
Background: In this report the phytochemical profile of Nitraria. Retusa (N. Retusa) leaf extracts were identified and their ability to induce apoptosis in human chronic myelogenous erythroleukaemia (K562) was evaluated.

Methods: Apoptosis of the human chronic myelogenous erythroleukaemia (K562) was evidenced by investigating DNA fragmentation, PARP cleavage and caspases 3 and 8 inducing activities, in the presence of $N$. retusa extracts.

Results: Our study revealed that the tested extracts from N. Retusa contain many useful bioactive compounds. They induced in a time-dependent manner the apoptosis the tested cancerous our cell line. This result was confirmed by ladder DNA fragmentation profile and PARP cleavage, as well as a release in caspase-3 and caspase-8 level.

Conclusion: Our results indicate that the tested compounds have a significant antiproliferative effect which may be due to their involvement in the induction of the extrinsic apoptosic pathway.
\end{abstract}

\section{Background}

Apoptosis is a form of cell death in which a programmed sequence of events eliminates cells without damaging neighbouring cells. Apoptosis is triggered through either a death receptor mediated extrinsic pathway or a mitochondrial intrinsic pathway. Phytotherapy is considered as an alternative, to mitigate side effects due the indiscriminate use of synthetic drugs. For many years, the antiproliferative actions of chemotherapeutic drugs were ascribed solely to their ability to induce genotoxic damage [1]. Therefore, the role of plant derived polyphenols in chemoprevention of cancer has emerged as an interesting area of research. To date, many anticancer drugs have been developed and applied by clinical doctors [2]. In addition flavonoids have been shown to cause apoptosis through induction of Bax with concomitant suppression of $\mathrm{Bcl}-2$, or through other molecules and pathways including up-regulation of death receptor 5, modulation of IGFBP-3, involvement of p38MAPK, and inhibition of PI-3-kinase/Akt and ERK

\footnotetext{
* Correspondence: I_chekir@yahoo.fr

'Laboratory of Cellular and Molecular Biology, Faculty of Dental Medicine,

University of Monastir, Rue Avicenne, Monastir, 5000, Tunisia

Full list of author information is available at the end of the article
}

pathways [3]. In our case, we were interested with leaf extracts from Nitraria retusa in order to investigate an alternative phytoterapy solution to current anticancerous treatments. Its fleshy red fruits are eaten by humans and are used to prepare drinks. The leaves serve as supplement for the tea and are used as poultice [4]. The ashes of this species have the ability to remove fluids of infected wounds [5]. Belkadhar [6] indicates that a decoction of fresh leaves of Nitraria retusa is used in Morocco in case of poisoning, upset stomach, ulcers, gastritis, enteritis, heartburn, colitis, colonic abdominal pain. In this study, we analyzed and compared cytotoxic effects of hexane, chloroform and methanol extracts, on a human chronic myelogenous erythroleukaemia (K562) cell line. We attempt to elucidate the apoptotic pathway and molecular mechanisms responsible for their cytotoxic and apoptotic activities.

\section{Methods \\ Reagents}

All the organic solvents were obtained from Carlo ERBA (Paris, France). L-glutamine was purchased from GIBCO BRL Life technologies (Grand Island, NY, USA). The chromatographic columns were performed with silica gel 60
C Biomed Central

(c) 2011 Boubaker et al; licensee BioMed Central Ltd. This is an Open Access article distributed under the terms of the Creative Commons Attribution License (http://creativecommons.org/licenses/by/2.0), which permits unrestricted use, distribution, and reproduction in any medium, provided the original work is properly cited. 
(Pharmacia Biotech, Uppsala, Sweden), reverse phase C18 column (Merck, Darmstadt, Hesse, Germany). The N-(1naphtyl) ethlenediaminedihydrochloride (EDTA) was purchased from Sigma-Aldrich (Steinheim, Germany). Dimethylsulfoxide (DMSO), monoclonal antibody i.e anti poly ADP-ribose polymerase (anti-PARP), goat anti mouse alkaline phosphtase conjugated antibody, caspase- 3 and caspase- 8 colorimetric assay kits and 3-(4, 5-dimethylthiazol-2-yl)-2, 5-diphenyl tetrazolium) (MTT) were purchased from Sigma RBI, (St.Louis, MO, USA). RPMI-1640, foetal bovine serum and gentamicin were bought from GIBCO BRL Life technologies (Grand Island, NY, USA). The proteinase $\mathrm{K}$, the sodium dodecyl sulfate (SDS), ribonuclease (RNase), Sarkosyl, Thiobarbituric Acid (TBA), and pyridine were purchased from Sigma Aldrich Co (St. Louis, MO, USA). Acrylamide and bisacrylamide, 5-bromo-4 chloro-3 indolyl phosphate (BCIP)/nitro blue tetrazolium (NBT) and tween 20, were purchased from promega (Madison, Wisconsin, USA). Ethidium bromide (EtBr) and bromophenol blue were purchased from Merck (Darmstadt, Hesse, Germany). Agarose and ployvinylidene difluoride (PVDF) membranes were obtained from Invitrogen, life technologies (Glasgow, UK). Acetic acid was procured from Panreac (Barcelone, Espagne).

\section{Plant Material}

Leaves of $N$. retusa were collected from saline soils in Sahline, a region situated in mid-Tunisia, in December 2006. Identification was carried out by Pr. M. Cheieb (Department of Botany, Faculty of Sciences, University of Sfax, Sfax, Tunisia), according to the Flora of Tunisia [7] and Contribution to ethnobotanical study of the flora of Tunisia [8]. A voucher specimen (N.r-12.06) was kept in our laboratory for future reference. The leaves were hade dried, powdered, and stored in a tightly closed container for further use.

\section{Preparation of plant extracts}

Three hundred and fifty grams of powder, from dried leaves, were sequentially extracted in a Soxhlet apparatus (6 h) (AM Glassware, Aberdeen, Scotland, United Kingdom) with hexane, chloroform, ethyl acetate and methanol solvents. We obtained the correspondent extracts for each solvent. Hexane (Hex), chloroform (Chl) and methanol $(\mathrm{MeOH})$ extracts, with different polarities, were concentrated to dryness and the residues were kept at $4^{\circ} \mathrm{C}$. Then, each extract was resuspended in dimethyl sulfoxide solvent (DMSO).

Preliminary phytochemical analysis and determination of Total Polyphenol, Flavonoid, Tannins and Sterol Contents Plant materials were screened for the presence of tannins, flavonoids, coumarins and sterols using the methods previously described by Tona et al. $[9,10]$.
The polyphenol content of $N$. retusa leaf extracts was quantified by the Folin-Ciocalteau reagent as described by Yuan et al. [11]. The Gallic acid $(0.2 \mathrm{mg} / \mathrm{ml})$ was used as a standard. The polyphenol content was expressed according to the following formula:

$\%$ Polyphenols $=\left(\left[\mathrm{A}_{(720 \mathrm{~nm})}\right.\right.$ extract $\left.\times 0.2\right) / \mathrm{A}_{(720 \mathrm{~nm})}$ Quercetin $] /$ Extract concentration $) \times 100$

However, flavonoid content was determined according to the modified method of Zhishen et al. [12]. The Quercetin $(0.05 \mathrm{mg} / \mathrm{ml})$ was used as a standard compound.

The flavonoïd content was expressed according to the following formula:

$\%$ Flavonoids $=\left(\left[\mathrm{A}_{(510 \mathrm{~nm})}\right.\right.$ extract $\left.\times 0.05\right) / \mathrm{A}_{(510 \mathrm{~nm})}$ Gallic acid $] /$ Extract concentration $) \times 100$

The total sterol content was evaluated as described by Skandrani et al. [13]. The sterol content was expressed according to the following formula:

$\%$ Sterols $=(\mathrm{W}$ steroids $/ \mathrm{W}$ extract $) \times 100$. Where Wsteroids $=(\mathrm{Wf}-\mathrm{WO}) \times 0.25$

MO: Weight filter (mg), Mf: Weight of filter with the precipitate (mg).

The method described by Pearson [14], was used for the determination of tannin content of samples which is evaluated according to the following formula:

$\%$ Tanins $=\left(\left[\mathrm{A}_{(760 \mathrm{~nm})}\right.\right.$ extract $\left./ . \varepsilon \times 1\right) /$ Extract concentration $\times 100$

where $\varepsilon$; molar extinction coefficient $(=1 \mathrm{~g}-1 \mathrm{~cm}-1)$ of tannic acid (= $3.27 \mathrm{lg}-1 \mathrm{~cm}-1)$

\section{Cell cultutre}

Human chronic myelogenous leukemia cell line K562 was obtained from the American Type Culture Collection (Rockville, MD). Cells were cultivated in RPMI-1640 medium supplemented with $10 \%(\mathrm{v} / \mathrm{v})$ foetal calf serum, $0.1 \mathrm{mg} / \mathrm{ml}$ gentamicin and $2 \mathrm{mM}$ L-glutamine as a complete growth medium and were incubated at 37$)^{\circ} \mathrm{C}$ in an incubator with $5 \% \mathrm{CO}_{2}$ in a humidified atmosphere. Every two days the cells were subcultured by splitting the culture with fresh medium.

\section{Assay for cytotoxic activity}

Cytotoxicity of Nitraria retusa extracts against K562 leukemia cells was estimated by the 3-(4, 5-dimethylthiazol2-yl)-2, 5-diphenyltetrazolium bromide (MTT) assay, based on the reduction of the MTT by mitochondrial dehydrogenases in viable cells. The resulting blue formazan product is measured spectrophotometrically [15]. Cells were seeded in a 96-well plate at a concentration of $5 \times 10^{4}$ cells/well and incubated at $37^{\circ} \mathrm{C}$ for $24 \mathrm{~h}$ in a $5 \%$ $\mathrm{CO}_{2}$ enriched atmosphere. The extracts were firstly dissolved in $1 \%$ DMSO, then in the cell growth medium. Cells were incubated again at $37^{\circ} \mathrm{C}$ for $48 \mathrm{~h}$ with each of 
the tested extract at concentrations ranging from 10 to $800 \mu \mathrm{g} / \mathrm{ml}$. Next, the medium was removed and cells in each well were incubated with $50 \mu$ of MTT solution $(5 \mathrm{mg} / \mathrm{ml})$ at $37^{\circ} \mathrm{C}$ for $4 \mathrm{~h}$. MTT solution was then discarded and $50 \mu \mathrm{l}$ of $100 \%$ DMSO were added to dissolve the insoluble formazan crystal. The optical density was measured at $540 \mathrm{~nm}$. Each drug concentration was tested in triplicate.

The cytotoxic effects of the extracts were estimated in terms of cell population growth inhibition percentage and expressed as $\mathrm{IC}_{50}$ which is the concentration of extract that reduces the absorbance of the treated cells by $50 \%$ with reference to the control (cells treated with DMSO). The $\mathrm{IC}_{50}$ values were graphically obtained from the dose-response curves. We determined $\mathrm{IC}_{50}$ values when cytotoxicity resulted more than $50 \%$ at screening concentrations.

\section{Evaluation of lipid peroxidation induction provoked by $\mathrm{H}_{2} \mathrm{O}_{2}$, using the thiobarbituric acid reactive substances (TBARS) assay}

The method known as thiobarbituric acid reactive species (TBARS) assay, concerns the spectrophotometric measurement of the pink pigment produced through reaction of thiobarbituric acid (TBA) with malondialdehyde (MDA) and other secondary lipid peroxidation products. TBARS were determined by previously described assay [16]. The cells $\left(3.510^{7}\right.$ cells $\left./ \mathrm{ml}\right)$ were exposed to various concentrations of each compounds (200, 400 and $800 \mu \mathrm{g} /$ $\mathrm{ml}$ of $\mathrm{MeOH}$ extract, 150, 300 and $600 \mu \mathrm{g} / \mathrm{ml}$ of hexane extract and 190, 380 and $760 \mu \mathrm{g} / \mathrm{ml}$ of chloroform extract) in the incubation medium during $2 \mathrm{~h}$, followed by incubation with $75 \mathrm{mM}_{\mathrm{H} 2 \mathrm{O} 2}$ for $2 \mathrm{~h}$. The ranges of doses of different tested compounds were chosen on basis of their cytotoxic activity. The cells were washed with PBS, pelleted and homogenized in $1.15 \% \mathrm{KCl}$. Samples were combined with $0.2 \mathrm{ml}$ of $8.1 \%$ SDS, $1.5 \mathrm{ml}$ of $20 \%$ acetic acid and $1.5 \mathrm{ml}$ of $0.8 \%$ thiobarbituric acid. The mixture was brought to a final volume of $4.0 \mathrm{ml}$ with distilled water and heated to $95^{\circ} \mathrm{C}$ for $120 \mathrm{~min}$. After cooling for $10 \mathrm{~min}$ on ice, $5.0 \mathrm{ml}$ of a mixture of $\mathrm{n}$-butanol and pyridine $(15: 1 \mathrm{v} / \mathrm{v})$ were added to each sample, and the mixture was shaken vigorously. After centrifugation at $825 \mathrm{~g}$ for $10 \mathrm{~min}$, the supernatant fraction was isolated and the absorbance was measured at $532 \mathrm{~nm}$. Lipid peroxidation effect was expressed as equivalent of MDA. Data were reported as mean \pm SD for triplicate determinations.

\section{DNA fragmentation analysis}

DNA fragmentation was analysed by agarose gel electrophoresis as described by Wang et al [17], with slight modifications. K562 cells (1.5 106 cells/ml) were exposed to various concentrations of each compounds (200, 400 and $800 \mu \mathrm{g} / \mathrm{ml}$ of $\mathrm{MeOH}$ extract, 150, 300 and $600 \mu \mathrm{g} / \mathrm{ml}$ of hexane extract and 190, 380 and $760 \mu \mathrm{g} / \mathrm{ml}$ of chloroform extract) for 24 and $48 \mathrm{~h}$ and harvested by centrifugation. Cell pellets were disolvedin $200 \mu \mathrm{l}$ of lysis buffer (50 mM Tris-HCl, pH 8.0, 10 mM EDTA, 0.5\% N-Lauroyl Sarcosine Sodium Salt) at room temperature for $1 \mathrm{~h}$ then centrifuged at $12000 \mathrm{~g}$ for $20 \mathrm{~min}$ at $4^{\circ} \mathrm{C}$. The supernatant was incubated overnight at $56^{\circ} \mathrm{C}$ with $250 \mu \mathrm{g} / \mathrm{ml}$ proteinase $\mathrm{K}$. Cell lysates were then treated with $2 \mathrm{mg} / \mathrm{ml} \mathrm{RNase} \mathrm{A} \mathrm{and} \mathrm{incubated} \mathrm{at} 56^{\circ} \mathrm{C}$ for $2 \mathrm{~h}$. DNA was extracted with chloroform/phenol/isoamyl alcohol (24/25/1, v/v/v) and precipitated from the aqueous phase by centrifugation at $14000 \mathrm{~g}$ for $30 \mathrm{~min}$ at $0^{\circ} \mathrm{C}$. The DNA solution was transferred to $1.5 \%$ agarose gel and electrophoresis was carried out at $67 \mathrm{~V}$ for $3 / 4 \mathrm{~h}$ with TAE (Tris $40 \mathrm{mM}$, sodium acetate $20 \mathrm{mM}$, EDTA $1 \mathrm{mM}$ ) as the running buffer. DNA in the gel was visualized with ethidium bromide $(0.5 \mu \mathrm{g} / \mathrm{ml})$ under UV light.

\section{Western blot analysis}

K562 cells $\left(1.510^{6}\right.$ cells $\left./ \mathrm{ml}\right)$ were exposed to various concentrations of each compounds $(200,400$ and $800 \mu \mathrm{g} / \mathrm{ml}$ of $\mathrm{MeOH}$ extract, 150, 300 and $600 \mu \mathrm{g} / \mathrm{ml}$ of hexane extract and 190, 380 and $760 \mu \mathrm{g} / \mathrm{ml}$ of chloroform extract) for 6, 24 and $48 \mathrm{~h}$. Cells were centrifuged at $3000 \mathrm{rpm}$ for $8 \mathrm{~min}$ at $25^{\circ} \mathrm{C}$ and lysed with a lysis buffer (62.5 mM Tris $\mathrm{Hcl}$ and $6 \mathrm{mM}$ urea, $\mathrm{pH}=6.8)$. Protein concentrations were determined in cell lysates using the Bradford method [18]. Equal amounts of proteins (40 mg) were separated by sodium dodecyl sulphate polyacrylamide gel electrophoresis (SDS-PAGE), and transferred into PVDF membrane, which was blocked with $5 \%$ non-fat milk in $0.1 \%$ Tween 20-phosphate buffer salin (PBST) overnight at $4^{\circ} \mathrm{C}$. Membranes were then incubated with a primary antibody antiPARP at a 1:100 dilution for $2 \mathrm{~h}$ at room temperature. The membrane was then washed and incubated with a goat anti-mouse alkaline phosphatase-conjugated antibody at 1:7500 dilution for $1 \mathrm{~h}$.

Next, the membrane was washed and the chromogenic substrate BCIP/NBT was added to localise antibody binding proteins. Protein levels were determined by computer assisted densitometric analysis (Densitometer, GS-800, Bio.Rad Quantity One).

\section{Investigation of caspase- 3 and caspase- 8 induction}

The cells were cultured $\left(10^{6}\right.$ cells $\left./ \mathrm{ml}\right)$ in $25 \mathrm{~cm}^{2}$ flasks for $24 \mathrm{~h}$ in the absence or the presence of extracts at $37^{\circ} \mathrm{C}$. Controls were performed at the same time with $0,5 \%$ DMSO. The cells were harvested and centrifuged at $600 \times$ $g$ and the pellets were incubated in ice cold lysis buffer (250 mM HEPES, pH 7.4, 25 mM CHAPS, 25 mM DTT) for $15 \mathrm{~min}$, then they were centrifuged at $16000 \times g$ for 20 min. Supernatants (cell extracts eventually containing caspase- 3 and caspase-8) were retrieved and aliquots 
corresponding to $50 \mu \mathrm{g}$ total protein were incubated along with acetylated tetrapeptide Ac-DEVD substrate labelled with the chromophore $p$-nitroaniline ( $p$-NA), $2 \mathrm{mM}$, for caspase 3 assay, or Ac-IETD- $p$-NA substrate, $2 \mathrm{mM}$, for caspase 8 assay, in the presence of each caspase buffer in a 96-well flat bottomed microplate.

In the presence of active caspase- 3 and caspase- 8 , cleavage and release of $p$-NA from the substrate occurs. Free $p$-NA produces a yellow colour detected spectrophotometrically at $405 \mathrm{~nm}$ against a blank performed at the same time and containing assay buffer (200 mM HEPES, pH 7.4, 1\% CHAPS, 50 mM DTT, 20 mM EDTA, for caspase 3 assay) and (200 mM HEPES, pH 7.4, 1\% CHAPS, $50 \mathrm{mM}$ DTT, $20 \mathrm{mM}$ EDTA, 50\% sucrose for caspase 8 assay) and substrate but without cell lysate. A standard curve was performed in order to determine the correspondence between absorbance and $p$-NA concentration, then the results were expressed as caspase- 3 and caspase- 8 specific activity ( $\mu \mathrm{mol} p$-NA per $\mathrm{min} / \mathrm{ml}$ protein) calculated as indicated by the manufacturer (Caspase-3, caspase-8, assay kit colorimetric, Sigma.)

\section{Statistical analysis}

Data were collected and expressed as the mean \pm standard deviation of three independent experiments and analyzed for statistical significance from control. The data were tested for statistical differences by one-way ANOVA followed by student test using statistica. The criterion for significance was set at $p<0.05$.

\section{Results}

Phytochemical study and determination of extract yield, total polyphenol, flavonoid, tannin and sterol contents of Nitraria retusa leaf extracts

Using $350 \mathrm{~g}$ of powder from the leaves of $N$ retusa, we obtained $50 \mathrm{~g}$ of $\mathrm{MeOH}$ extract, $10 \mathrm{~g}$ of Hex extract and 6 $\mathrm{g}$ of $\mathrm{Chl}$ extract, corresponding to yields of $14.30 \%, 3.50 \%$, and $1.71 \%$ respectively (Table 1 ).

The highest content of polyphenols was recorded in Chl extract. In fact, the percentage of the total polyphenolic content in chloroform extract was $10.03 \%$. The Hex extract showed the presence of an important quantity of sterols equivalent to $31 \%$. Whereas, $\mathrm{MeOH}$ extract exhibited the highest quantities of tannins and flavonoids. The percentages of tannins and flavonoids in $\mathrm{MeOH}$ extract were respectively $18.84 \%$ and $14.82 \%$ (Table 2 ).

\section{Evaluation of the cytotoxicity of extracts}

We have examined the effect of different concentrations (200, 400 and $800 \mu \mathrm{g} / \mathrm{ml}$ ) of each extract on the $\mathrm{K} 562$ cell population growth in-vitro, using the MTT assay. The results of this assay are reported in Figure 1. Hex and $\mathrm{Chl}$ extracts inhibited strongly the malignant tested cell population growth $\left(\mathrm{IC}_{50}\right.$ values were 300 and $380 \mu \mathrm{g}$ /
Table 1 Phytochemical screening of extracts from Nitraria retusa:

\begin{tabular}{cccc}
\hline & Hex extract & Chl extract & MeOH extract \\
\hline Sterols & ++++ & ++ & - \\
Flavonoids & - & - & +++ \\
Tanins & - & - & +++ \\
Coumarins & - & ++ & - \\
polyphenols & - & ++ & + \\
Yield $(\%)$ & 3.5 & 1.71 & 14.3 \\
\hline$-=$ not detectable; $+=$ low quantitiy; $++=$ average quantitiy $+++=$ high
\end{tabular}

$\mathrm{ml}$ respectively). However, no significant cytotoxic activity was revealed in the presence of $\mathrm{MeOH}$ extract $\left(\mathrm{IC}_{50}>\right.$ $800 \mu \mathrm{g} / \mathrm{ml})$.

Effect of extracts on lipid peroxidation induced by $\mathrm{H}_{2} \mathrm{O}_{2}$ The reaction of MDA with TBA has been widely adopted as a sensitive assay method for lipid peroxidation. The effect of different concentrations of Nitraria retusa extracts on malondialdehyde (MDA) production in $\mathrm{K} 562$ cells, induced by $\mathrm{H}_{2} \mathrm{O}_{2}$, is shown in (Table 3 ). Hexane and chloroform extracts showed a protective effect against lipid peroxidation induced by $\mathrm{H}_{2} \mathrm{O}_{2}$ at the highest tested concentrations. The lipid peroxidation effect evaluated as MDA equivalent produced determined by using the TBARS test, were 150, and $190 \mathrm{nM}$ at a concentration of $600 \mu \mathrm{g} / \mathrm{ml}$ of Hex extract and $760 \mu \mathrm{g} / \mathrm{ml}$ of Chl extract. All the other tested concentrations for each extract showed an amplifying action of $\mathrm{H}_{2} \mathrm{O}_{2}$ pro-oxidant effect. In fact the obtained values were higher than those showed with $\mathrm{H}_{2} \mathrm{O}_{2}$ only ( $\left.225 \mathrm{nM}\right)$. While, $\mathrm{MeOH}$ extract showed a $\mathrm{H}_{2} \mathrm{O}_{2}$ pro-oxidant amplifying effect at all the tested concentrations, whereas alone it did not exhibit any inductive effect of lipid peroxidation (data not shown).

\section{Induction of apoptotic DNA fragmentation by Nitraria} retusa extracts on leukemia cells

At exposure with different concentrations of Hex extract (Figure 2, tracks B, C, D), Chl extract (Figure 2, tracks E, F, G) and $\mathrm{MeOH}$ extract (Figure 2, tracks H, I, J) during $48 \mathrm{~h}$, a fragmented DNA profile was clearly observed in

Table 2 Quantitative phytochemical screening of extracts from Nitraria retusa leaves

\begin{tabular}{llll}
\hline Extract content (\%) & Hex extract & $\begin{array}{l}\text { Chl extract } \\
\text { extract }\end{array}$ & MeOH extract \\
\hline Tanins(\%) & - & - & $18.84 \pm 0.002$ \\
Flavonoid(\%) & - & - & $14.82 \pm 0.009$ \\
Polyphenols (\%) & - & $10.03 \pm 0.008$ & $3.3 \pm 0.006$ \\
sterols(\%) & $31 \pm 0.02$ & $11.75 \pm 0.007$ & - \\
\hline
\end{tabular}

(results are represented by the means \pm SD of three experiments) 


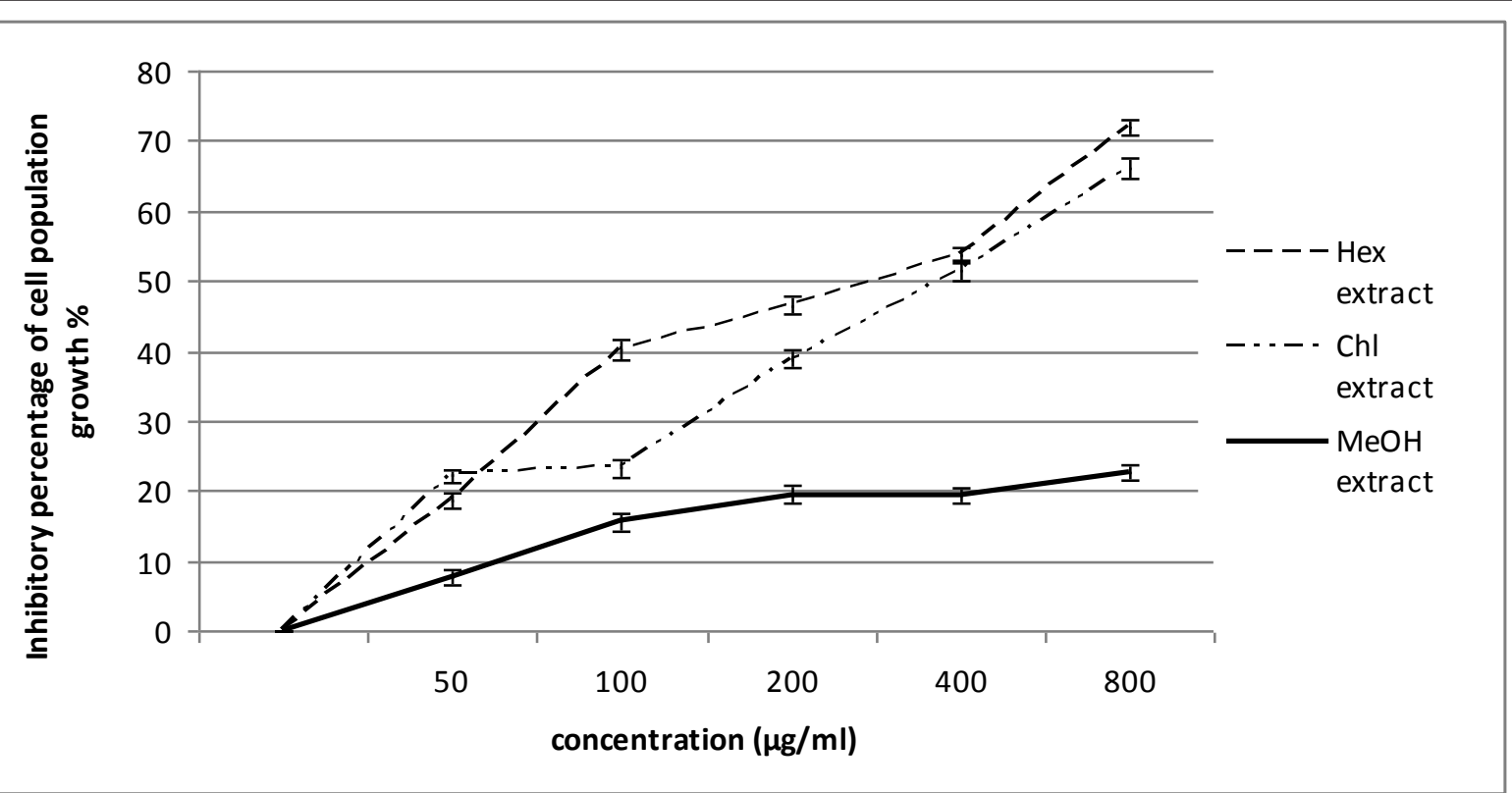

Figure 1 Inhibitory effect, of Nitraria retusa extracts on the viability of K562 cells. Results are represented by the means \pm SD of $n=3$. $\left(^{*}\right)$ $p<0.05$ means a significant difference between the untreated and treated cells. Hex: hexane extract, Chl: chloroform extract, MeOH: methanol extract.

K562 cells, compared to untreated cells which did not provide a ladder DNA profile (Figure 2, track A).

\section{Effect of Nitraria retusa extracts on the proteolysis of PARP}

DNA fragmentation is often associated with the activation of a family of cysteine proteases, the caspases. Caspase-3, in particular, seems to play an important role in several models of apoptosis [19]. To confirm the apoptotic process, generally admitted when a ladder DNA

Table 3 Lipid peroxidation inhibitory activity in $\mathrm{K} 562$ cells treated with $\mathrm{Hex}, \mathrm{Chl}$ and $\mathrm{MeOH}$ extracts against $\mathrm{H}_{2} \mathrm{O}_{2}(50 \mu \mathrm{M})$ induced peroxidation

\begin{tabular}{|c|c|c|}
\hline extraits & ${\text { Concentration }(\mu \mathrm{g} / \mathrm{ml})^{a}}^{a}$ & Concentration of MDA (nM) \\
\hline \multirow[t]{3}{*}{ Hex } & 150 & $260 \pm 16$ \\
\hline & 300 & $230 \pm 11$ \\
\hline & 600 & $150 \pm 10$ \\
\hline \multirow[t]{3}{*}{ Chl } & 190 & $245 \pm 15$ \\
\hline & 380 & $220 \pm 14$ \\
\hline & 760 & $190 \pm 20$ \\
\hline \multirow[t]{3}{*}{$\mathrm{MeOH}$} & 200 & $250 \pm 10$ \\
\hline & 400 & $265 \pm 5$ \\
\hline & 800 & $315 \pm 10$ \\
\hline $\mathrm{H}_{2} \mathrm{O}_{2}$ & $50 \mu \mathrm{M}$ & $225 \pm 5$ \\
\hline
\end{tabular}

${ }^{a}$ results are represented by the means \pm SD of three experiments (*) $p<0.05$ means a significant difference between the treated cells with different extracts and treated cells with hydrogen peroxide $\left(\mathrm{H}_{2} \mathrm{O}_{2}\right)$. fragmentation profile is observed, we investigated the enzymatic activation of apoptotic proteins by measuring the cleavage of PARP $(116 \mathrm{kDa})$, which is a caspase- 3 substrate, into fragments of 85 and $31 \mathrm{kDa}$.

As shown in (Figure 3.A and 4.A), when cells were treated with Hex and Chl extracts, the $116 \mathrm{kDa}$ band disappears after $48 \mathrm{~h}$ treatment and the band of a $85 \mathrm{kDa}$ arises. Whereas when incubated with $\mathrm{MeOH}$ extract, $\mathrm{K} 562$ cells exhibited a non fragmented band pattern after $6 \mathrm{~h}$ and 24 $\mathrm{h}$ incubation. This band disappears totally after $48 \mathrm{~h}$ of incubation. However we observed a decrease of the 116 $\mathrm{kDa}$ band intensity, after $24 \mathrm{~h}$ incubation, and at the same time a $85 \mathrm{kDa}$ band appears. The intensity of this band was higher in cells treated by extract for $48 \mathrm{~h}$ than for 24 h. (Figure 5.A)

\section{Caspase- 3 and caspase- 8 activation assay}

As the proapoptotic PARP is a substrate of caspases, we attempt to investigate the cellular pathway of cell death induced by Nitraria retusa extracts, by assessing caspase- 3 and caspase- 8 activities. These two proteins play a critical role in apoptosis. Following $24 \mathrm{~h}$ and $48 \mathrm{~h}$ treatment of K562 cells with various concentrations of Nitraria retusa extracts, caspase- 3 and caspase- 8 activities were measured and compared to those of control cells. As shown in Figures 6 and 7, K562 cells treated with Nitraria retusa extracts, showed a significant concentration-depending increase of caspase- 3 and caspase- 8 activities after 48 incubation with Hex and Chl extracts, and after 24 and $48 \mathrm{~h}$ 

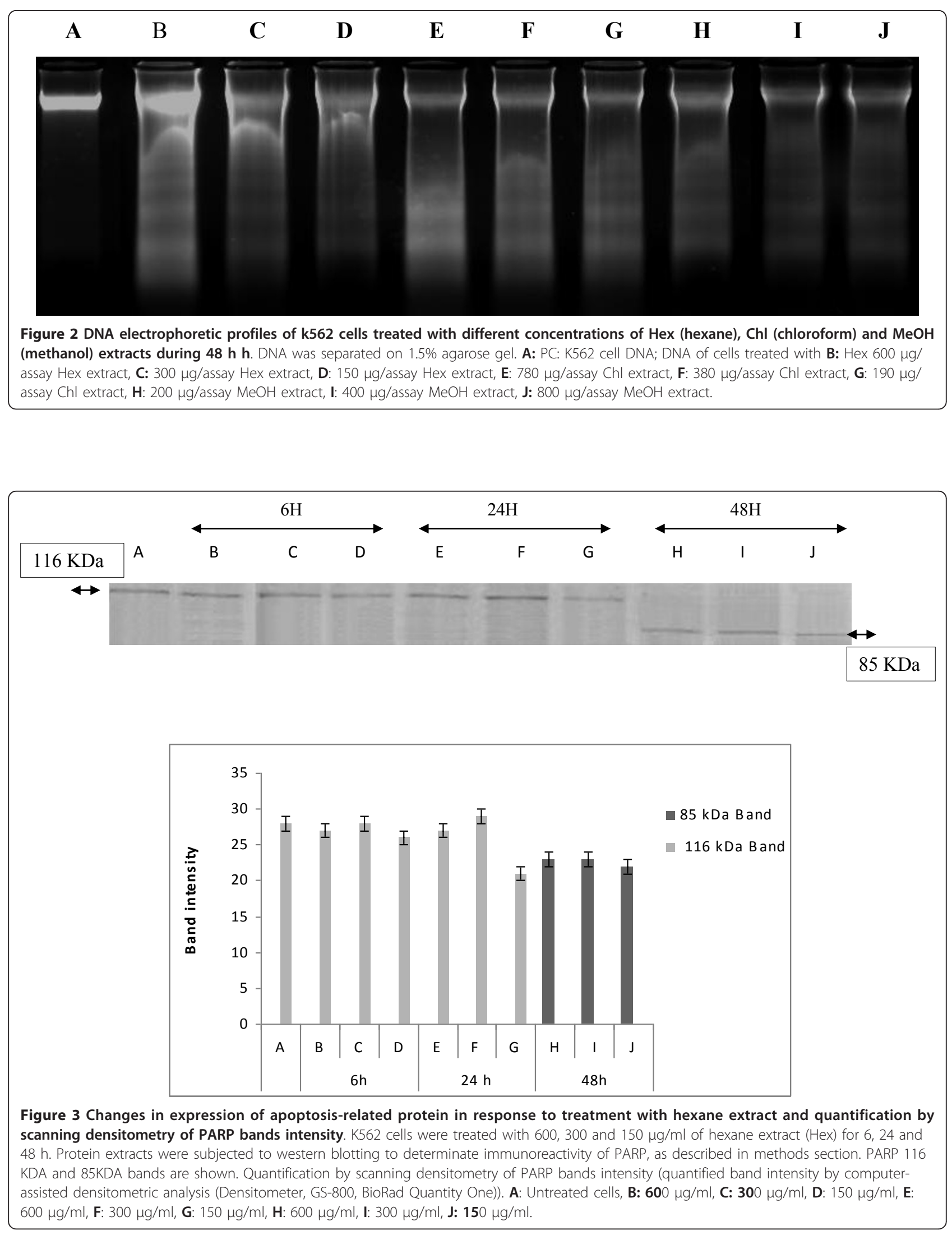


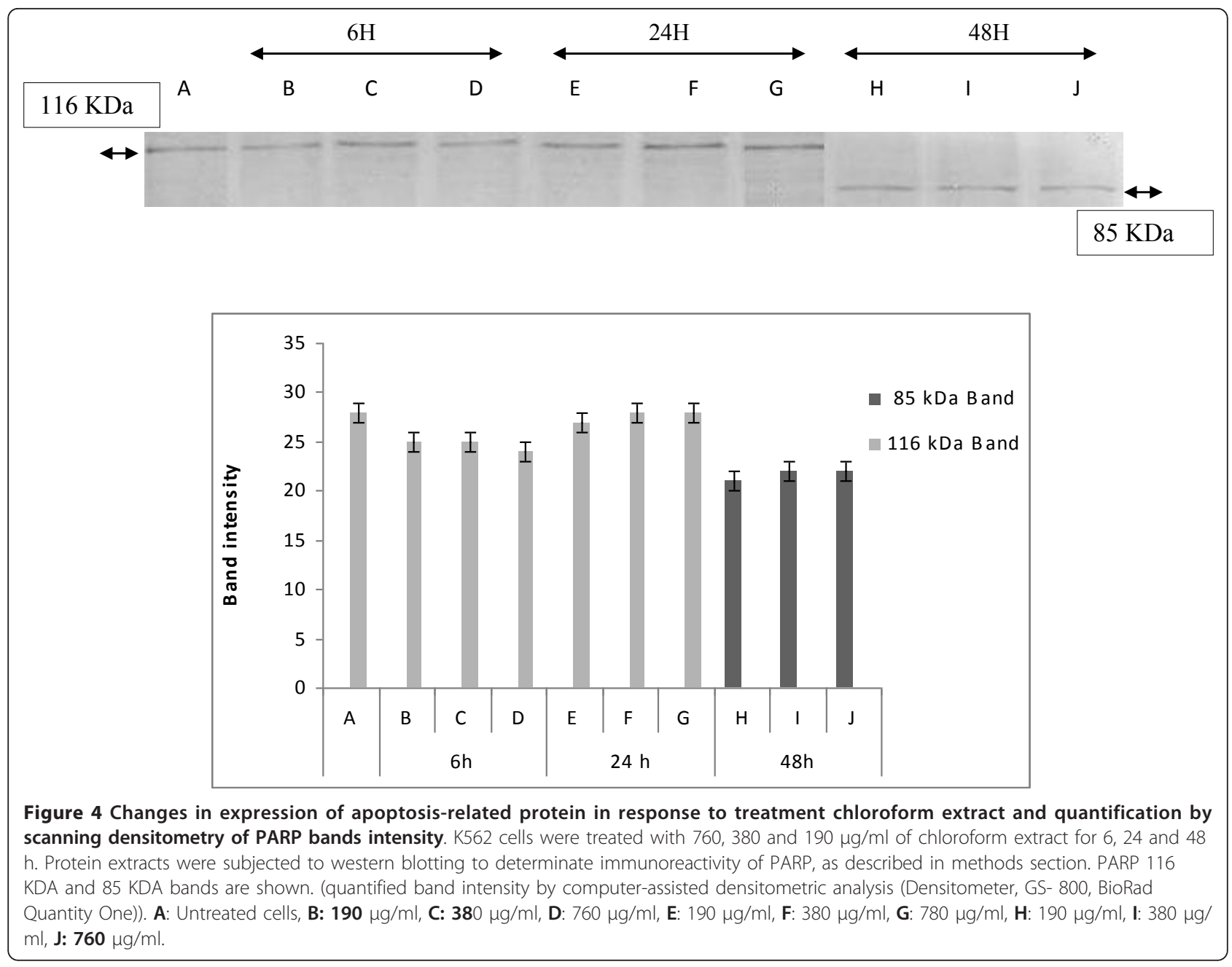

inubation with $\mathrm{MeOH}$ extract. These results suggest that apoptosis induced by the tested Nitraria retusa extracts may occur through the activation of common executors of apoptosis such as caspase- 3 by the activation of caspase- 8 .

\section{Discussion}

The relationship between concentration of extracts and their antiproliferative effect on K562 cells was investigated by MTT assay. $\mathrm{Hex}, \mathrm{MeOH}$ and $\mathrm{Chl}$ extracts possess an inhibitory effect on $\mathrm{K} 562$ cell proliferation. The strong antiproliferative activity of Hex may be due to the presence of sterols, which are known to induce antiproliferative effect [20]. In fact, Phytosterols seem to act through multiple mechanisms of action, including inhibition of carcinogen production, cancer-cell growth, angiogenesis, invasion and metastasis, and through the promotion of apoptosis of cancerous cells stress [21]. Inhibition of proliferation of K562 cells exhibited by Chl extract may be attributed to the presence of specific components such as polyphenols [13]. Besides, some studies have shown that polyphenols are able to influence a variety of cell function by modulating cell signalling [22], altering proliferation and induction anti-proliferative effect in cancer cell lines [23]. In fact, polyphenols exhibited antiproliferative effects on various cancerous human cell lines, for example leukaemia cells [24] and ovarian cancer cells [25]. However, minor components could also contribute to the antiproliferative effect of these extracts; they may be involved in some types of synergism with other active compounds [26]. The weak antiproliferative activity exhibited by the $\mathrm{MeOH}$ extract should be ascribed to its low polyphenol content fraction, if compared to Hex and Chl extracts. Nonetheless, polyphenols contained in $\mathrm{MeOH}$ extract should be different from those Chl extract as far as they were extracted with solvents having different polarities.

Membrane lipids are rich in unsaturated fatty acids that are most susceptible to oxidative processes. It is generally thought that the inhibition of lipid peroxidation by antioxidants may be due to their free radical-scavenging activities. The data obtained showed that Hex and Chl extracts exhibited better antioxidant activity at the highest tested concentrations than $\mathrm{MeOH}$ extract. We can 


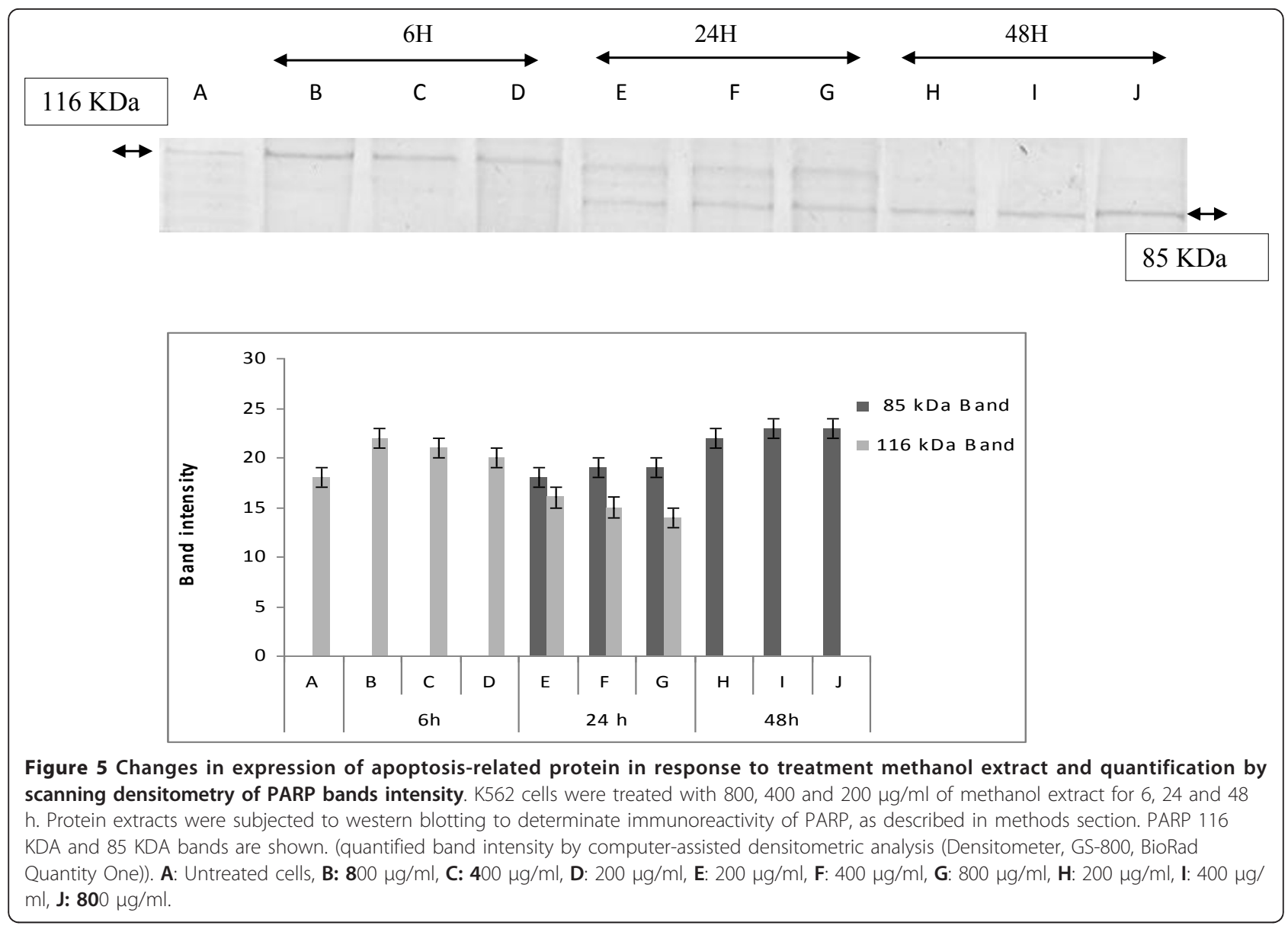

deduce that sterols which are the main constituents of Hex extract, and sterol and polyphenolic compounds which are the main constituents of Chl extract, should participate in the protective effect, of these two extracts at the highest tested concentration, against lipid peroxidation induced by $\mathrm{H}_{2} \mathrm{O}_{2}$ in $\mathrm{K} 562$ cells. This protective effect is absent at the lowest tested concentrations of the above mentioned extracts. In fact the lowest tested concentrations of both extracts did not exhibit a protective effect against lipid peroxidation induced by $\mathrm{H}_{2} \mathrm{O}_{2}$, as far as the rates of MDA formation obtained when cells are incubated with both $\mathrm{H}_{2} \mathrm{O}_{2}$ and each of these concentrations are in the same range as those obtained when cells are incubated with $\mathrm{H}_{2} \mathrm{O}_{2}$ alone. These results are in accordance with those of Mahoney and Graf [27] who showed that ascorbic acid initiates the formation of $\mathrm{OH}^{*}$ at low concentrations and scavenges radicals at high concentrations. It is possible that these compounds inhibit the free radicals and ROS produced by oxidation and redox-cycling started by $\mathrm{H}_{2} \mathrm{O}_{2}$ and leading to cell lipid peroxidation. Although $\mathrm{MeOH}$ extract contains flavonoids, tannins and polyphenols, it exhibits no protective effect against lipid peroxidation induces by $\mathrm{H}_{2} \mathrm{O}_{2}$. We believe that its weak polyphenol content and absence of sterols may explain the absence of protective effect against lipid peroxidation. In fact, polyphenols are an important group of pharmacologically active compounds, they are considered to be the most active antioxidant derivatives in plants. However, it has been shown that the phenolic content does not necessarily follow the antioxidant activity. Antioxidant activity is generally the result of the combined activity of a wide range of compounds, including phenolics, peptides, organic acids and other components [28].

However some flavonoids and polyphenols as catechol or pyrogallol may exhibit a prooxidant activity by generating free radicals, under certain conditions [29].

Our hypothesis that sterol contents of both Chl and Hex extracts are involved in their antioxidant effect is in accordance with the results described by Wang et al. [30], who reported the antioxidant capacity of some plant sterols. In fact, it is possible that sterols inhibit free radicals and ROS produced by oxidation and redox-cycling, as reported by Argolo et al. [31] and Ben Mansour et al. [32].

An oxidative stress probably provoked by extracts would lead to the formation of free radicals being able 


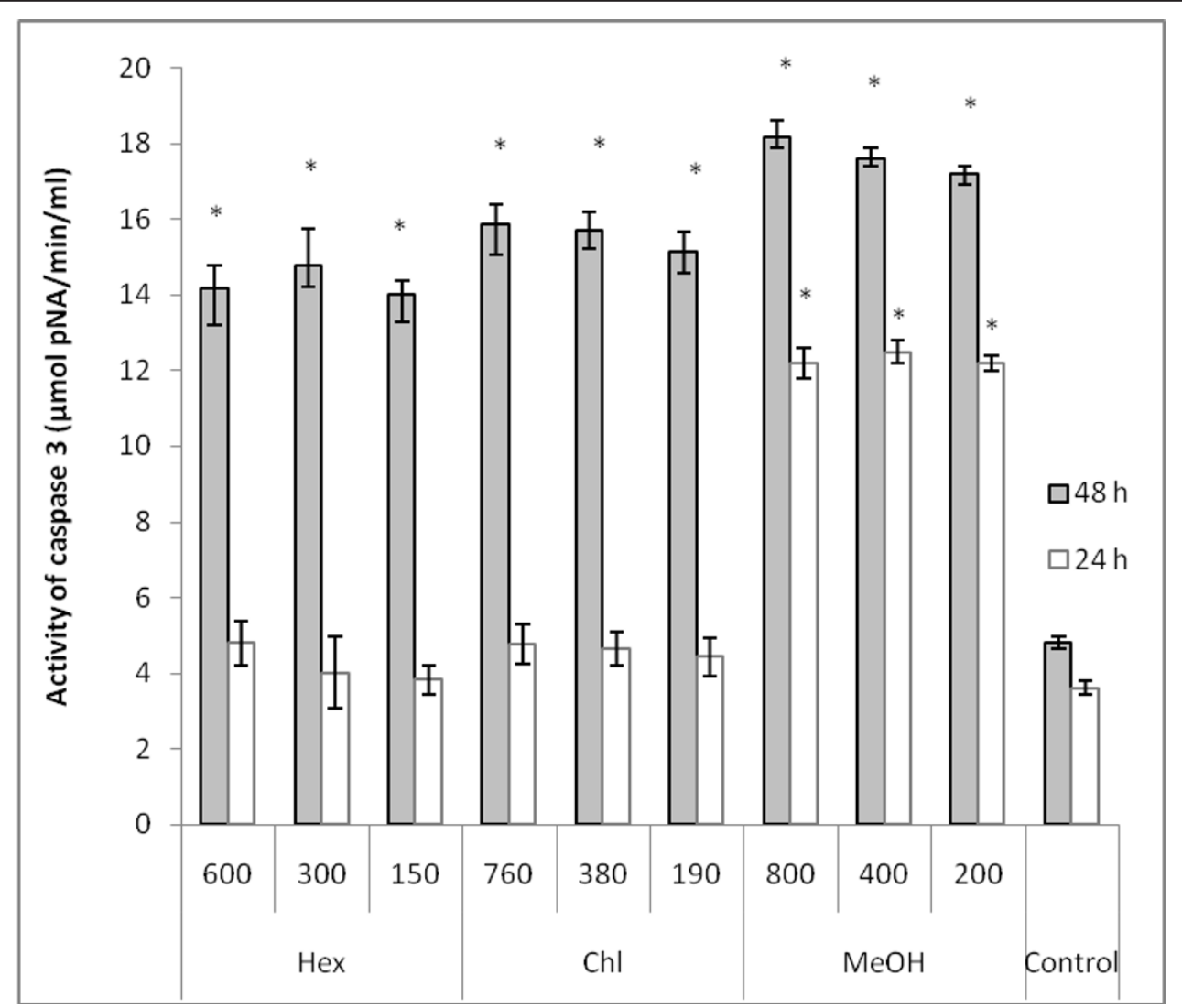

Figure 6 Effect of Hex, Chl and MeOH extracts on caspase-3 activity in K562 cells. Lysates prepared from cells treated with N. retusa leaf extracts for $24 \mathrm{~h}$ and $48 \mathrm{~h}$, were assayed for in vitro caspase-3 activity. The rate of cleavage of the caspase substrate DEVD-pNA was measured at $405 \mathrm{~nm}$. The results are presented as the mean \pm SD. The experiments were done in triplicate. $\left(^{*}\right) p<0.05$ means a significant difference between the control and treated cells Control: cells treated by the vehicle only.

to induce cellular stress, as cell DNA degradation and membrane permeabilization especially mitochondrial membranes, provoking liberation of pro-apoptotic proteins as pro-caspases, cytochrome $C$, which interact with proteins as Apaf-1 and pro-caspase- 9 forming, in the presence of ATP, a multi-protein complex named "apoptosome". This complex should allow the cleavage of caspase-9. This later will activated executive caspases as capases-3, 7 and 8, involved in the induction of apoptotic process. On the other hand, cell stress induced by free radicals should also activate a pro-apoptotic gene family (Bax, Bak, Bid, Bad, Bim) or inactivate anti-apoptotic genes as Bcl-2, Bcl-xL [33], inducing thus cell apoptotic process.

The antiproliferative activity of $\mathrm{MeOH}$ extract from $N$. retusa should be attributed to the presence of specific types of flavonoids and polyphenols [13]. In fact, some studies have shown that flavonoids [23] and tannins [34] are able to altering proliferation in cancer cell lines. Previous studies have shown that flavonoids induce apoptosis of various tumor cells including K562. This effect has also been observed in other tumor cell lines from gastric, colon and lung carcinomas [35]. In addition, flavonoids also inhibited tumor growth through cell cycle arrest and induced apoptosis through a p53-dependent mechanism [36].

Although $N$. retusa extracts should contain some antioxidant entities (revealed by antiradical properties of the same $N$. retusa extracts against several free radicals; data not shown), we believe that this dual property, reported also in other works [37] is not in contradiction with our aforementioned deduction, as several researchers have shown that antioxidants, such as retinoids and vitamin E, produce genetic changes that cause apoptosis in cancer cells by mechanisms other than a direct antioxidant effect [38].

The typical DNA fragmentation pattern which is considered as the hallmark of apoptosis, was observed in cancerous cells treated with the tested N.retusa leaf extracts. As far as the extracts tested in the present study were in crude form and probably contained many compounds which may well act synergistically. It is not possible to say which compounds are responsible for the observed effects. However, our data suggest that the biological effects 


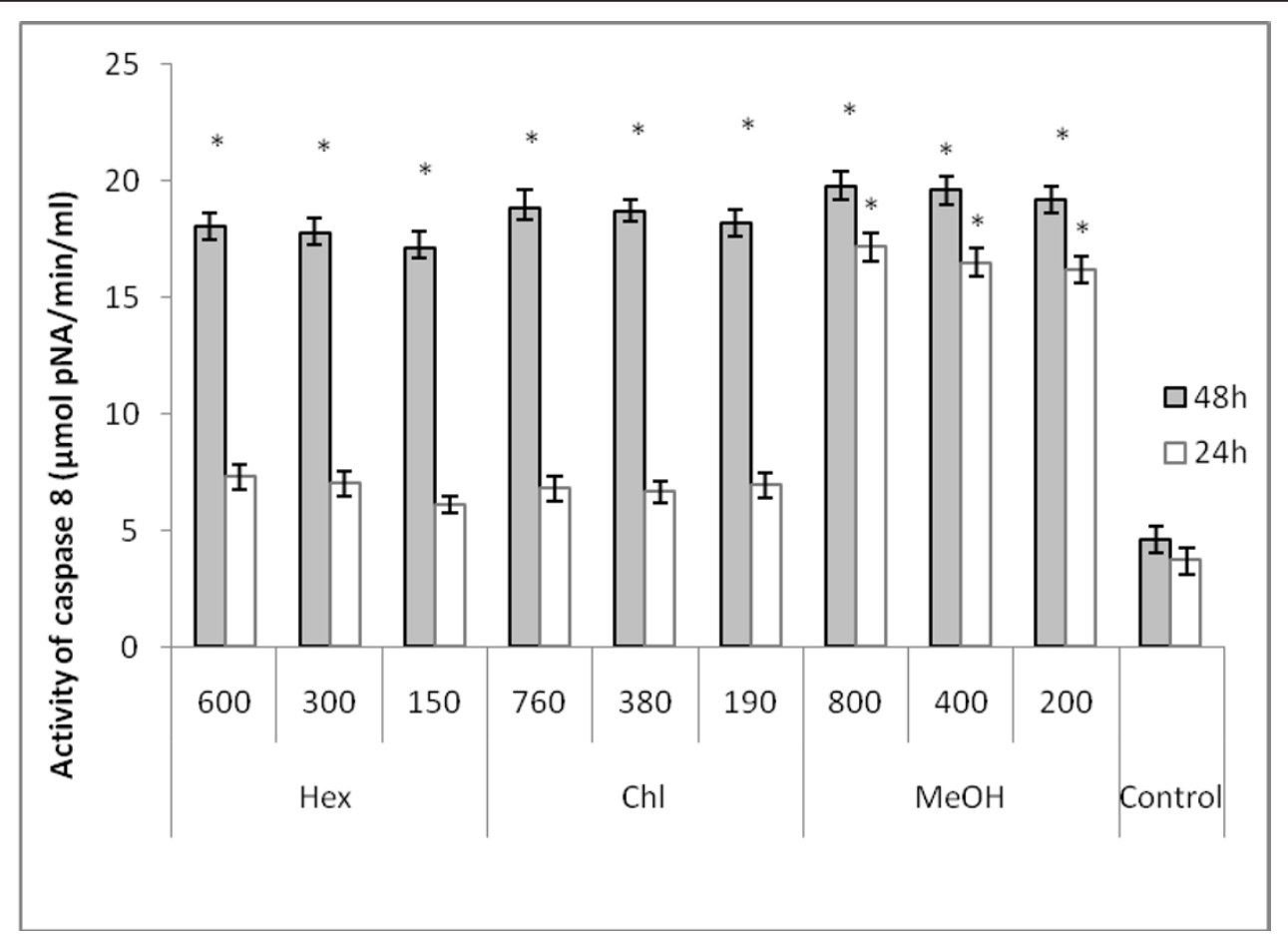

Figure 7 Effect of Hex, $\mathrm{Chl}$ and $\mathrm{MeOH}$ extracts on caspase-8 activity in $\mathrm{K} 562$ cells. Lysates obtained from cells treated with Nitraria retusa leaf extracts $24 \mathrm{~h}$ and $48 \mathrm{~h}$ were assayed for in vitro caspase-8 activity. The rate of cleavage of the caspase substrate IETD-pNA was measured at $405 \mathrm{~nm}$. The results are presented as the mean \pm SD. The experiments were done in triplicate. $\left({ }^{*}\right) p<0.05$ means a significant difference between the control and treated cells Control: cells treated by the vehicle only.

exhibited by this plant, under these experimental conditions, could be related to an overall effect of the tannins, flavonoids, sterols and coumarins present in these extracts. Phenolic compounds were postulated as effective in inducing apoptosis and as anticancer agents [39].

Likewise steroids showed growth inhibition of human prostate cancer PC-3 cells, being effective in inducing apoptosis [40].

As far as we obtained at all tested concentrations of different extracts, the activation of caspases 3 and 8, as well as the more effective PARP cleavage effect, after $48 \mathrm{~h}$ of incubation, we can deduce that the tested extracts should provoke a cytotoxic effect towards K562 cells by activating the extrinsic pathway of apoptosis. In fact, activation of caspase 8 leads to the activation of caspase 3 and subsequently induces PARP cleavage (the $116 \mathrm{kDa}$ band disappears in favour of $85 \mathrm{kDa}$ band) and DNA fragmentation (ladder electrophoretic profile). However we can not exclude the participation of other pathways in the apoptotic effect exhibited by these extracts.

\section{Conclusion}

In summary, N.retusa leaf extracts appear to contain compounds with, antiproliferative and apoptotic properties. The three tested extracts induced apoptotic effect by the activation of the extrinsic apoptotic pathway. As apoptosis has become a new therapeutic target in cancer research, it appears reasonable to suggest that N.retusa may have potential as an agent of chemotherapeutic and cytostatic activity in human leukaemia lymphoma.

\section{Acknowledgements}

The authors acknowledge the "Ministry of Higher Education, Scientific Research and Technology, Tunisia", for the support of this study and to the Pr Lotfi Chouchene and all members of the laboratory of Immunology, Faculty of Medicine, Monastir, Tunisia.

\section{Author details}

'Laboratory of Cellular and Molecular Biology, Faculty of Dental Medicine, University of Monastir, Rue Avicenne, Monastir, 5000, Tunisia. ${ }^{2}$ Unity of Pharmacognosy/Molecular Biology, Faculty of Pharmacy, University of Monastir, Rue Avicenne, Monastir, 5000, Tunisia.

\section{Authors' contributions}

BJ:Was responsible for the conception and design, testing and data acquisition, analysis and data interpretation and drafted the manuscript. BW: made contribution to the study of caspase activities. BSG:made contribution to cell culture and the study of the DNA fragmentation.

IB:made contribution to cell culture and the study of the cytotoxicity. SI: made contribution to data interpretation and drafted the manuscript. GK: made substantial contribution to conception and revised it critically for importantintellectual content. CGL:made substantial contribution to conception and revised it critically for important intellectual content. All authors read and approved the final manuscript.

\section{Competing interests}

The authors declare that they have no competing interests. 
Received: 3 June 2011 Accepted: 31 October 2011

Published: 31 October 2011

\section{References}

1. Skandrani I, Boubaker J, Bhouri W, Limem I, Kilani S, Ben Sghaier M, Neffati A, Bouhlel I, Ghedira K, Chekir L: Leaf extracts from Moricandia arvensis promote antiproliferation of human cancer cells, induce apoptosis and enhance antioxidant activity. Drug Chem Toxicol 2009.

2. Yang LL, Lee CY, Yen KY: Induction of apoptosis by hydrolysable tannins from Eugenia jambos L on human leukaemia cells. Cancer.Lett 2000, 157:65-75

3. Zhang Q, Zhao XH, Wang ZJ: Flavones and flavonols exert cytotoxic effects on a human oesophageal adenocarcinoma cell line (OE33) by causing G2/M arrest and inducing apoptosis. Food Chem Toxicol 2008, 46:2042-2053.

4. Boubaker J, Skandrani I, Bouhlel I, Ben sghaier M, Neffati A, Ghedira K, Chekir-Ghedira L: Mutagenic, antimutagenic and antioxidant potency of leaf extracts from Nitraria retusa. Food and Chem Toxicol 2010, 48:2283-2290.

5. Passager $P$, Barbançon S: Taghit (Shara Oranais): Etude historique, géographique et médicale. Arch Inst Pasteur, Alger 1956, 34:404-475.

6. Bellakhdar J: La pharmacopée marocaine traditionnelle: Médecine arabe ancienne et savoirs populaires. Ibis Press; 1997, 764

7. Pottier-Alapetite G: Flore de la Tunisia: angiospermes, dicotyledones, apetales, dialypetales Tunisia: Ministère de L'enseignement Supérieur et de la Recherche Scientifique et Ministère de l'Agriculture; 1979, 456.

8. Boukef K: Contribution à une etude ethnobotaque de la flore de Tunisie Tunisia: Ministère de L'enseignement Supérieur et de la Recherche Scientifique et Ministère de l'Agriculture; 1983, 136-137.

9. Tona L, Kambu K, Ngimbi N, Cimanger K, Vlietnick AJ: Antiamoebic and phytochemical screening of some congolesse medical plants. Ethnopharmacol 1998, 61:57-65

10. Tona L, Cimanga RK, Mesia K, Musuamba CT, De Bruyne T, Apers S, Hernans N, Von Miert S, Pieters L, Totté J, Vlietinck AJ: In vitro antiplasmodial activity of extracts and fractions from seven medicinal plants used in Democratic Republic of Congo. J Ethnopharmacol 2004, 93:27-32.

11. Yuan VY, Bone DE, Carrington F: Antioxidant activity of dulse (Palmaria palmata) extract evaluated in vitro. Food Chem 2005, 91:485-494.

12. Zhishen J, Mengcheng T, Jianming $W$ : The determination of flavonoid contents in mulberry and their scavenging effects on superoxide radicals. Food Chem 1999, 64:555-559.

13. Skandrani I, Ben Sghaier M, Neffati A, Boubaker J, Bouhlel I, Kilani S, Mahmoud A, Ghedira K, Chekir-Ghedira L: Antigenotoxic and free radical scavenging activities of extracts from Moricandia arvensis. Drug Chem Toxicol 2007, 30:361-382

14. Pearson D: The Chemical Analysis of Foods, London. 7 edition. Churchil Livingstone; 1976, 572

15. Carmichael J, DeGraff WG, Gazdar AF, Minna JD, Mitchell JB: Evaluation of a tetrazolium-based semiautomated colorometric assay; assessment of chemosensitivity testing. Cancer Res 1987, 47:936-942.

16. Ohkawa H, Ohishi N, Yagi K: Assay for lipid peroxide in animal tissues by thiobarbituric acid reaction. Anal.Biochem 1979, 95:351-358.

17. Wang IK, Lin-Shiau SY, Lin JK: Induction of Apoptosis by Apigenin and Related Flavonoids Through Cytochrome c Release and Activation of Caspase-9 and Caspase-3 in Leukaemia HL-60 Cells. European Journal of Cancer 1999, 35(10):1517-1525.

18. Bradford MM: A Rapid and Sensitive Method for the Quantitation of Microgram Quantities of Protein Utilizing the Principle of Protein-Dye Binding. Ann Biochem 1976, 72:248-254.

19. Martin SJ, Newmeyer DD, Mathias S, Farschon DM, Wang HG, Reed JC, Kolesnick RN, Green DR: Cell-free reconstitution of Fas- UV radiation- and ceramide-induced apoptosis. EMJ 1995, 14:5191-5200.

20. Samina N, Russell GK, Ramaswamy N: New antiproliferative epoxysecosterols from Pseudopterogorgia Americana. Tetrahedron.Lett 2000, 41:6035-6040.

21. Woyengo TA, Ramprasath VR, Jones PJ: Anticancer effects of phytosterols. Eur J Clin Nutr 2009, 63(7):813-820.

22. Musonda CA, Chipman JK: Quercetin inhibits hydrogen peroxide ( $\left.\mathrm{H}_{2} \mathrm{O} 2\right)$ induced NF-KB DNA binding activity and DNA damage in HepG2 cells. Carcinogenesis 1998, 19:1583-1589.
23. Kuntz S, Wenzel $U$, Daniel $H$ : Comparative analysis of effects of flavonoids on proliferation, antiproliferativeity and apoptosis in human colon cancer cell lines. Eur J Nutr 1999, 38:133-142.

24. Hirano T, Gotoh M, Oka K: Natural flavonoids and lignans are potent cytostatic agents against human leukemic HL 60 cells. Life Sci 1994, 55:1061-1069.

25. Benavente-Garcia O, Casillo O, Marin F, Ortuno A, Del-Rio J: Uses and properties of citrus flavonoids. J Agric Food Chem 1997, 45:4505-4515.

26. $\mathrm{Yu}$ J, Lei J, Yu H, et al: Chemical Composition and Antimicrobial Activity of the Essential Oil of Scutellaria barbata. Phytochern 2004, 65:881-884.

27. Mahoney JR, Graf E: Role of a-Tocopherol, Ascorbic Acid, Citric Acid and EDTA as Oxidants in Model Systems. Food Sci 1986, 51:1293-I 296

28. Gallardo C, Jimenez L, Garcia-Conesa MT: Hydroxycinnamic acid composition and in vitro antioxidant activity of selected grain fractions. Food Chem 2006, 99:455-463

29. Cao G, Sofic E, Prior RL: Antioxidant and prooxidant behaviors of flavonoids: structure activity relationships. Free Radic Biol Med 1997, 22:749-760.

30. Wang T, Hicks KB, Moreau R: Antioxidant activity of phytosterols, oryzanol and other phytosterols conjugates. J.A.O.C.S 2002, 79:1201-1206.

31. Argolo ACC, Sant'Ana AEF, Pletsch M, Coelho LCBB: Antioxidant activity of leaf extracts from Bauhinia monandra. Bioresource Technology 2004, 95:229-233.

32. Ben Mansour H, Boubaker J, Bouhlel I, Mahmoud A, Bernillon S, Ben Chibani J, Ghedira K, Chekir-Ghedira L: Antigenotoxic activities of crude extracts from Acacia salicina leaves. Environmental and Molecular Mutagenesis 2007, 48:58-66.

33. Adam JM, Cory S: The Bcl-2 protein family: arbiters of cell survival. Science 281:1322-6.

34. Amit K, Taraphdar R, Madhumita R, Bhattacharya RK: Natural products as inducers of apoptosis: Implication for cancer therapy and prevention. Curr Sci 2001, 80:11-10.

35. Wei $Y Q$, Zhao X, Kariya $Y$, Fukata H, Teshigawara K, Uchida A: Induction of apoptosis by quercetin: involvement of heat shock protein. Cancer Res 1994, 54:4952-4957.

36. Plaumann B, Fritsche $\mathrm{M}$, Rimpler $\mathrm{H}$, Brandner $\mathrm{G}$, Hess RD: Flavonoids activate wild-type p53. Oncogene 1996, 13:1605-1614.

37. Turley E, McKeown A, Bonham MP, O'Connor JM, Chopra M, Harvey LJ, Majsak-Newman G, Fairweather-Tait SJ, Bugel S, Sandstrom B, Rock E, Mazur A, Rayssiguier Y, Strain JJ: Copper supplementation in humans does not affect the susceptibility of low density lipoprotein to in vitro induced oxidation. Free Radic Biol Med 2000, 29:1129-1134

38. Zou C, Liebert M, Zou C, Grossman HB, Lotan R: Identification of effective retinoids for inhibiting growth and inducing apoptosis in bladder cancer cells. J Urol 2001, 165:986-992.

39. Surh YJ: Molecular mechanisms of chemopreventive effects of selected dietary and medicinal phenolic substances. Mutat Res 1999, 428:305-327.

40. Awad AB, Burr AT, Fink CS: Effect of resveratrol and beta-sitosterol in combination on reactive oxygen species and prostaglandin release by PC-3 cells. P.L.E.F.A 2005, 72:219-226.

doi:10.1186/1475-2867-11-37

Cite this article as: Boubaker et al: Leaf extracts from Nitraria retusa promote cell population growth of human cancer cells by inducing apoptosis. Cancer Cell International 2011 11:37.

\section{Submit your next manuscript to BioMed Central and take full advantage of:}

- Convenient online submission

- Thorough peer review

- No space constraints or color figure charges

- Immediate publication on acceptance

- Inclusion in PubMed, CAS, Scopus and Google Scholar

- Research which is freely available for redistribution 